\title{
Análises de extrações de DNA: ponto de partida para aplicações biotecnológicas na área da biologia molecular
}

Diego Hepp Instituto Federal de Educação, Ciência e Tecnologia do Rio Grande do Sul (IFRS) Campus Porto Alegre (diego.hepp@poa.ifrs.edu.br)

Jordânia Santos Pinheiro Instituto Federal de Educação, Ciência e Tecnologia do Rio Grande do Sul (IFRS) Campus Porto Alegre (jordaniaspinheiro@gmail.com)

Milena Flor Instituto Federal de Educação, Ciência e Tecnologia do Rio Grande do Sul (IFRS) Campus Porto Alegre (milenaflor62@hotmail.com)

\section{Bruna Bernar Dias}

Instituto Federal de Educação, Ciência e Tecnologia do Rio Grande do Sul (IFRS)

Campus Porto Alegre (bruna_bernar_dias@hotmail.com)

Rudá Ferreira Morais Instituto Federal de Educação, Ciência e Tecnologia do Rio Grande do Sul (IFRS) Campus Porto Alegre (udaferreiramorais_9@hotmail.com)

\section{Gabriela Ribeiro Borges} Instituto Federal de Educação, Ciência e Tecnologia do Rio Grande do Sul (IFRS)

Campus Porto Alegre (gabibiborges@gmail.com) 
Jair Renato Silva da Silva Junior Instituto Federal de Educação, Ciência e Tecnologia do Rio Grande do Sul (IFRS) Campus Porto Alegre (junior_cmpa@hotmail.com) Juliana Schmitt de Nonohay
Instituto Federal de Educação, Ciência e Tecnologia do Rio Grande do Sul (IFRS) -
Campus Porto Alegre
(juliana.nonohay@poa.ifrs.edu.br)

Resumo: A Biologia Molecular constitui importante área da Biotecnologia relacionada com variadas análises da informação genética contida nas moléculas de DNA e RNA. A disciplina de Biologia Molecular do Curso Técnico em Biotecnologia, do Instituto Federal de Educação, Ciência e Tecnologia do Rio Grande do Sul - Campus Porto Alegre (IFRS-POA), aborda o estudo de processos, análises e técnicas moleculares e, entre as técnicas, a extração de DNA, que também têm sido objeto de pesquisa de projetos desenvolvidos no IFRS-POA. Este artigo visa relatar estas pesquisas, que analisaram diferentes variáveis das extrações de DNA, incluindo: análise do melhor protocolo para tecidos vegetais (folhas); quantidade de tecido e volume de soluções utilizadas para extração de DNA de tecido animal (músculo bovino) e formas de conservação das amostras de tecido bovino até o momento da extração. O desenvolvimento destes projetos de pesquisa resultou em dados importantes, quanto ao rendimento e qualidade de extrações de DNA de tecidos vegetais e animais, e que poderão contribuir no apuramento de métodos subsequentes de análises moleculares.

Palavras-chave: Biotecnologia; Biologia Molecular; Extração de DNA.

\title{
Analysis of DNA extractions: starting point for biotechnological applications in the area of molecular biology
}

\begin{abstract}
The molecular biology is an important field of Biotechnology focused on different analyses of the genetic information held in the DNA and RNA molecules. The Molecular Biology course is part of the Technical Biotechnology Program, of the Federal Institute of Education, Science, and Technology of Rio Grande do Sul - Porto Alegre Campus (IFRS-POA), and includes studies on processes, analyses, and molecular techniques. The studied techniques include the extraction, quantification, and analysis of biological DNA samples that have been studied in researches developed in the Campus. This article aims to report the objectives, methods, and main results of these researches. Several DNA extraction parameters were analyzed, such as the evaluation of the best protocol for vegetal tissues, the number of animal tissue and solutions, the degradation rate, and forms of animal sample conservation until the extraction moment. The results showed the importance of such evaluations to improve the quality and efficiency of DNA extractions, hence improving the subsequent methods of molecular analysis.
\end{abstract}

Keywords: Biotechnology; Molecular Biology; DNA Extraction. 


\section{INTRODUÇÃO}

A área das Ciências Biológicas, denominada Biologia Molecular, emergiu a partir da dedução da estrutura da molécula de DNA, o ácido desoxirribonucléico. O DNA é de fundamental importância na existência da vida, por ser a molécula que armazena as informações genéticas dos indivíduos, passadas de geração em geração, e por determinar a produção das moléculas de RNA (ácidos ribonucléico) e proteínas nas células. As proteínas, juntamente com os glicídios, lipídios, vitaminas, sais minerais e RNAs, determinam o fenótipo, ou seja, a morfologia, fisiologia e mesmo o comportamento dos indivíduos de todas as espécies.

A Biologia Molecular constitui destacado campo da Biotecnologia, relacionada a clonagens de indivíduos e genes, obtenção de organismos transgênicos, sequenciamento de genes e genomas, identificação de indivíduos, diagnóstico molecular de doenças, entre inúmeros exemplos. Desta forma é importante que cursos de Biotecnologia, em seus diferentes níveis de formação, tenham Biologia Molecular entre as disciplinas ofertadas, tal como ocorre no Curso Técnico em Biotecnologia do Instituto Federal de Educação, Ciência e Tecnologia do Rio Grande do Sul - Campus Porto Alegre (IFRS-POA).

$\mathrm{Na}$ disciplina de Biologia Molecular, do Curso Técnico em Biotecnologia do IFRS-POA, as aulas práticas são focadas nas técnicas básicas e principais para o funcionamento de um laboratório da área, tais como: extração de DNA, análise do DNA extraído pelas técnicas de espectrofotometria e eletroforese em gel, amplificação de DNA pela reação em cadeia da polimerase (PCR) e análise dos resultados dos testes de DNA por eletroforese. Entre estas técnicas, a extração de DNA, além de ser trabalhada nas aulas práticas e teóricas do Curso Técnico em Biotecnologia, tem sido objeto de estudo de linha de pesquisa do grupo de pesquisa "Núcleo Interdisciplinar de Estudos em Biotecnologia (NIEB)", do Campus Porto Alegre do IFRS.

A extração de DNA se destaca por constituir o ponto de partida para as demais técnicas de Biologia Molecular, como PCR, sequenciamento de DNA, clonagem de genes, realizadas nas diferentes análises moleculares. Nesse sentido, este artigo visa apresentar quatro projetos de pesquisa desenvolvidos por grupo de pesquisa do NIEB, que objetivaram aprimorar e alargar o entendimento sobre os diferentes aspectos de extrações de DNA. 
As pesquisas foram desenvolvidas de forma subsequente, sendo os principais resultados obtidos aplicados no projeto seguinte. O primeiro projeto analisou 0 melhor protocolo de extração de DNA, entre três, para tecidos vegetais (folhas). $\mathrm{O}$ segundo projeto avaliou a quantidade inicial de tecido animal (músculo bovino) e volumes de solução de extração e do sobrenadante retirado na etapa de purificação, em dois protocolos de extração de DNA. E os dois últimos projetos analisaram formas de conservação de amostras de tecido bovino, até o momento da extração de DNA, utilizando diferentes temperaturas e conservantes.

O trabalho está organizado de forma que, inicialmente, está descrita a metodologia geral, comum aos quatro projetos, e, após, informações específicas de cada pesquisa.

\section{DESCRIÇÃO DOS PROJETOS DE PESQUISA}

\section{METODOLOGIA GERAL}

Os quatro projetos de pesquisa empregaram pelo menos um de três protocolos de extração de DNA: (1) protocolo desenvolvido para vegetais por Doyle e Doyle (1990), com pequenas modificações como a maceração das amostras diretamente na solução tampão de extração, caracterizado pelo uso do detergente brometo de cetiltrimetilamônio (CTAB); (2) protocolo que utiliza alta concentração salina ("salting out"), de Miller et al. (1988) e (3) protocolo que utiliza partículas de sílica (kit comercial; BOOM et al. 1990). Os protocolos foram respectivamente denominados de "CTAB", "salting out" e "sílica".

As soluções utilizadas nos três protocolos, em cada uma das cinco principais etapas da técnica de extração de DNA, estão apresentadas na Tabela 1. Observa-se que as diferenças entre os três protocolos ocorrem nas etapas iniciais, de lise celular e purificação das extrações (Tabela 1). No protocolo "CTAB" há o uso do detergente CTAB e do antioxidante $\beta$-mercaptoetanol na lise celular e de clorofórmio na purificação. No protocolo "salting out", o reagente $\beta$-mercaptoetanol, também foi utilizado, mas o detergente é o dodecil sulfato de sódio (SDS) e a purificação das amostras foi realizada com cloreto de sódio ( $\mathrm{NaCl}$ ). No kit comercial, o detergente foi o Triton, o sal utilizado foi o tiocianato de guanidina e partículas de sílica são utilizadas para isolar as moléculas de DNA. 
Análises de extrações de DNA: ponto de partida para aplicações biotecnológicas na área da biologia molecular

Tabela 1 - Soluções utilizadas nas cinco principais etapas de extração de DNA nos protocolos "CTAB", "salting out" e "sílica".

\begin{tabular}{|c|c|c|c|}
\hline \multirow{2}{*}{$\begin{array}{c}\text { ETAPAS } \\
\text { EXTRAÇÃO DE } \\
\text { DNA }\end{array}$} & \multicolumn{3}{|c|}{ PROTOCOLOS } \\
\hline & “CTAB” & "Salting out" & “Sílica” \\
\hline 1. Lise celular & $\begin{array}{c}\text { Tampão de lise } \\
\text { (CTAB } 2 \% \text {, Tris } 0,1 \mathrm{M} \text {, } \\
\text { EDTA } 0,02 \mathrm{M} \text { e } \mathrm{NaCl} \\
1,4 \mathrm{M})+\beta- \\
\text { mercaptoetanol } 1 \%\end{array}$ & $\begin{array}{c}\text { Tampão de lise } \\
\text { (SDS } 2 \% \text {, Tris 0,1M, } \\
\text { EDTA 0,02M e NaCl } \\
1 \mathrm{M} \text { ) e } \beta \text { - } \\
\text { mercaptoetanol } \\
0,2 \%\end{array}$ & $\begin{array}{c}\text { Tampão de lise (tiocianato } \\
\text { de guanidina 3M, Tris } \\
0,1 \mathrm{M} \text { e Triton 1\%) + } \\
\text { suspensão de sílica }\end{array}$ \\
\hline 2. Purificação & $\begin{array}{l}\text { Clorofórmio/álcool } \\
\text { isoamílico }(24: 1)\end{array}$ & $\mathrm{NaCl} 5 \mathrm{M}$ & $\begin{array}{c}\text { Tiocianato de guanidina } \\
3 \mathrm{M} \text { e Tris } 1 \mathrm{M}\end{array}$ \\
\hline 3. Precipitação & Álcool etílico absoluto & $\begin{array}{l}\text { Álcool etílico } \\
\text { absoluto }\end{array}$ & Álcool etílico absoluto \\
\hline 4. Lavagem & Etanol $70 \%$ & Etanol $70 \%$ & Etanol $70 \%$ \\
\hline 5. Ressuspensão & $\begin{array}{c}\text { Tampão TE (Tris } \\
0,1 \mathrm{M} \text { e EDTA } 0,5 \mathrm{M})\end{array}$ & $\begin{array}{c}\text { Tampão TE (Tris } \\
0,1 \mathrm{M} \text { e EDTA 0,5M) }\end{array}$ & $\begin{array}{c}\text { Tampão TE (Tris } 0,1 \mathrm{M} \text { e } \\
\text { EDTA } 0,5 \mathrm{M})\end{array}$ \\
\hline
\end{tabular}

Fonte: Os autores com base nos trabalhos de MILLER et al. (1988); BOOM et al. (1990);

DOYLE e DOYLE, (1990).

Nas extrações, as amostras de tecido vegetal ou animal foram pesadas em balança, com auxílio de pinças e tesouras previamente limpas com etanol e flambadas, a fim de evitar contaminação. As amostras foram submetidas imediatamente a extração ou conservadas em tubos de microcentrífuga (com ou sem conservantes) até o momento da extração.

Nos quatro projetos, na avaliação do resultado das extrações, a quantidade de DNA obtido foi determinada pelo método de espectrofotometria. Neste método, a quantidade de luz absorvida (absorbância) pela solução com DNA, no comprimento de onda de $260 \mathrm{~nm}$, apresenta correlação positiva com a concentração de DNA na amostra (SAMBROOK e RUSSEL, 2001). Após a obtenção do valor da absorbância (A) da amostra, aplica-se a fórmula [DNA $\left.(n g / \mu L)=A_{260 n m} \times F D \times 50\right]$ para a 
determinação da concentração de DNA, considerando-se também o fator de diluição (FD) e o valor padrão de $A=1$, que corresponde a uma concentração de $50 \mathrm{ng}$ de DNA por microlitro $(\mu \mathrm{L})$.

A determinação da qualidade das amostras foi igualmente realizada por espectrofotometria, com mediação adicional de absorbância das amostras a $280 \mathrm{~nm}$ de comprimento de onda. Nesta avaliação, a proporção das absorbâncias medidas nos dois comprimentos de onda $(260 \mathrm{~nm} / 280 \mathrm{~nm})$ indica o índice adequado de pureza das amostras de DNA, que deve estar entre 1,6 e 2,0. Valores abaixo ou acima podem significar a presença de proteínas, RNAs ou outros contaminantes nas extrações.

\section{DESCRIÇÃO ESPECÍFICA DE CADA PROJETO DE PESQUISA}

Os objetivos, material e métodos específicos e os principais resultados de cada projeto de pesquisa estão a seguir descritos.

\section{Avaliação da eficiência de três protocolos de extração de DNA para pitanga (Eugenia uniflora L.)}

Este estudo avaliou os três protocolos de extração de DNA ("CTAB", "Salting out" e "sílica") para tecidos vegetais, no caso folhas de pitanga (Eugenia uniflora L.). As extrações de DNA foram a partir de $50 \mathrm{mg}$ de folhas jovens de 16 plantas para cada um dos três protocolos, em um total de 48 amostras.

As extrações de DNA foram quantificadas por espectrofotometria e os resultados obtidos para cada protocolo foram: (1) "CTAB" - concentração média de $315,94 \mathrm{ng} / \mu \mathrm{L}$ (desvio padrão de 131,11 ng/ $\mu \mathrm{L}$ ) e média do índice de pureza das

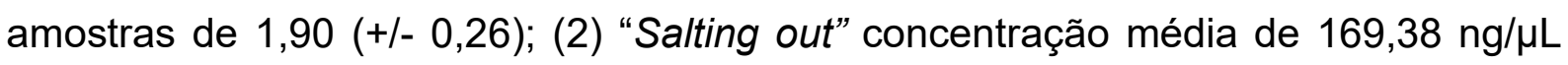
(+/- 78,05 ng/ $\mu \mathrm{L})$ e média do índice de pureza das amostras de 1,23 (+/- 0,24); (3) "Sílica" - concentração média foi $115,63 \mathrm{ng} / \mu \mathrm{L}(+/-27,58 \mathrm{ng} / \mu \mathrm{L})$, e índice de pureza de 1,06 (+/-0,06), conforme representado na Figura 1. 
Figura 1 - Resultado das quantificações das extrações de DNA de folhas de pitanga nos três protocolos.

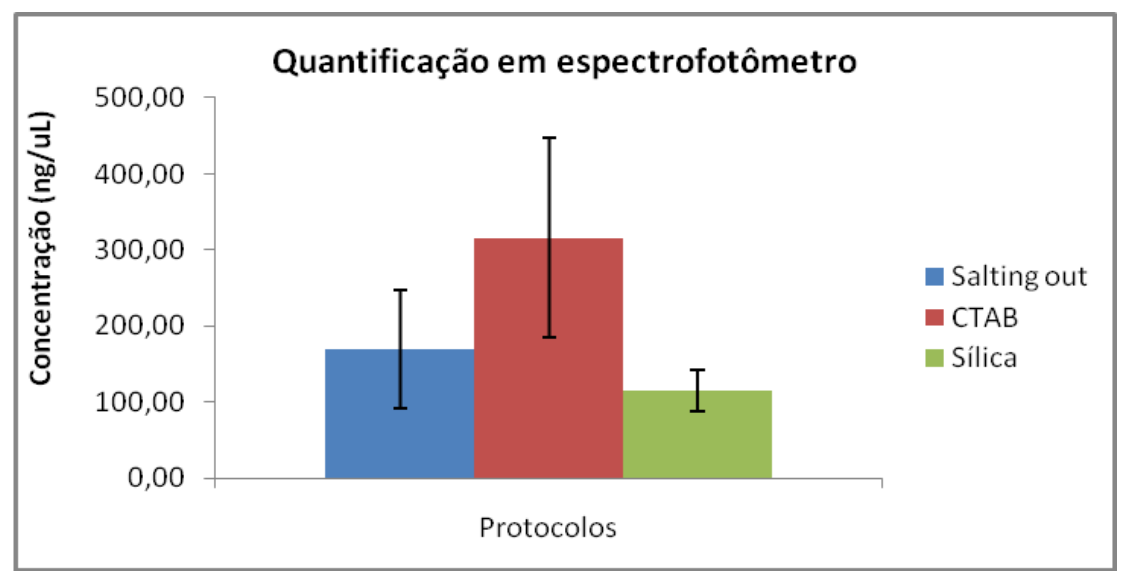

Fonte: os autores.

$\mathrm{Na}$ avaliação dos resultados, o protocolo "CTAB" mostrou-se como o mais adequado para extração de DNA de folhas, apresentando maior concentração de ácidos nucléicos e menor interferência de outras moléculas, especialmente proteínas, que os demais protocolos. Estes resultados foram confirmados em análise de qualidade e quantificação por eletroforese em gel adicionalmente realizada (dados não apresentados).

\section{Modificação em variáveis de dois protocolos de extração de DNA a partir de tecido animal (músculo bovino)}

O objetivo do segundo projeto foi avaliar modificações nos protocolos "CTAB" e "Salting out", visando a melhoria das variáveis de concentração, rendimento e pureza do DNA obtido. As modificações avaliadas nos protocolos foram quanto a: quantidade de tecido inicial (tratamento A), volume da solução tampão de extração (tratamento B) e volume de sobrenadante (fase aquosa com DNA) transferido durante a etapa de purificação (tratamento C). No delineamento experimental foram determinadas seis repetições amostrais para cada protocolo, por tratamento. Os melhores valores obtidos nos tratamentos foram adotados para uso no tratamento seguinte.

A Tabela 2 expressa as médias dos resultados obtidos no tratamento $A$, quanto as variáveis de concentração de DNA, rendimento das extrações, índice de 
pureza das amostras e coeficiente de variação entre as amostras em relação às quantidades iniciais de tecido bovino, para os protocolos "CTAB" e "Salting out".

Tabela 2 - Média dos resultados obtidos (6 repetições) nos dois protocolos.

\begin{tabular}{|c|c|c|c|c|c|}
\hline Protocolo & $\begin{array}{l}\text { Quantidade } \\
\text { de tecido } \\
\text { (mg) }\end{array}$ & $\begin{array}{l}\text { Concentração } \\
\text { de DNA ( } \mu / L)\end{array}$ & $\begin{array}{c}\text { Rendimento } \\
(\mu \mathrm{g} / \mathrm{mg})\end{array}$ & Pureza & $\begin{array}{c}\text { Coeficiente } \\
\text { de } \\
\text { variação } \\
(\%) \\
\end{array}$ \\
\hline \multirow{5}{*}{ “CTAB” } & 30 & 0,17 & 0,58 & 1,97 & 20,84 \\
\hline & 60 & 0,35 & 0,57 & 1,97 & 35,22 \\
\hline & 120 & 0,76 & 0,64 & 1,81 & 17,22 \\
\hline & 250 & 1,55 & 0,61 & 1,89 & 14,79 \\
\hline & 310 & 1,54 & 0,49 & 1,96 & 9 \\
\hline \multirow{5}{*}{$\begin{array}{l}\text { "Salting } \\
\text { out" }\end{array}$} & 30 & 0,22 & 0,74 & 1,87 & 32,33 \\
\hline & 60 & 0,41 & 0,68 & 1,62 & 15,97 \\
\hline & 120 & 0,76 & 0,63 & 1,83 & 14,29 \\
\hline & 250 & 0,94 & 0,37 & 1,90 & 14,88 \\
\hline & 310 & 1,26 & 0,4 & 1,94 & 20,86 \\
\hline
\end{tabular}

Fonte: os autores.

No tratamento A observou-se que o aumento da quantidade de tecido inicial resultou em maior concentração média de DNA obtido, conforme o esperado. Entretanto, o rendimento das extrações, ou seja, a relação entre a quantidade de DNA obtido e a quantidade inicial de tecido, não aumentou proporcionalmente. Houve um decréscimo de rendimento para as quantidades iniciais de tecido de 250 $\mathrm{mg}$ e $310 \mathrm{mg}$, em ambos protocolos.

Com base nesta avaliação, a quantidade de $120 \mathrm{mg}$ de tecido bovino foi considerada como a mais adequada para extração de DNA, em ambos protocolos. Esta avaliação foi corroborada pelos valores médios intermediários dos coeficientes de variação, observados para a quantidade inicial de tecido de $120 \mathrm{mg}$ (Tabela 2). Os resultados obtidos para o protocolo "CTAB" podem também ser observados na Figura 2. O coeficiente de variação se refere a variabilidade nos resultados dentro de cada grupo. Quanto ao índice de pureza das amostras, todos os valores médios ficaram dentro do intervalo de 1,6 a 2,0, indicando boa qualidade de todas as amostras. 
Figura 2 - Efeito de 5 diferentes quantidades iniciais de tecido bovino $(\mathrm{mg})$ em relação a concentração média e coeficiente de variação $(\mu \mathrm{g} / \mu \mathrm{L})$ das extrações de DNA no protocolo "CTAB".

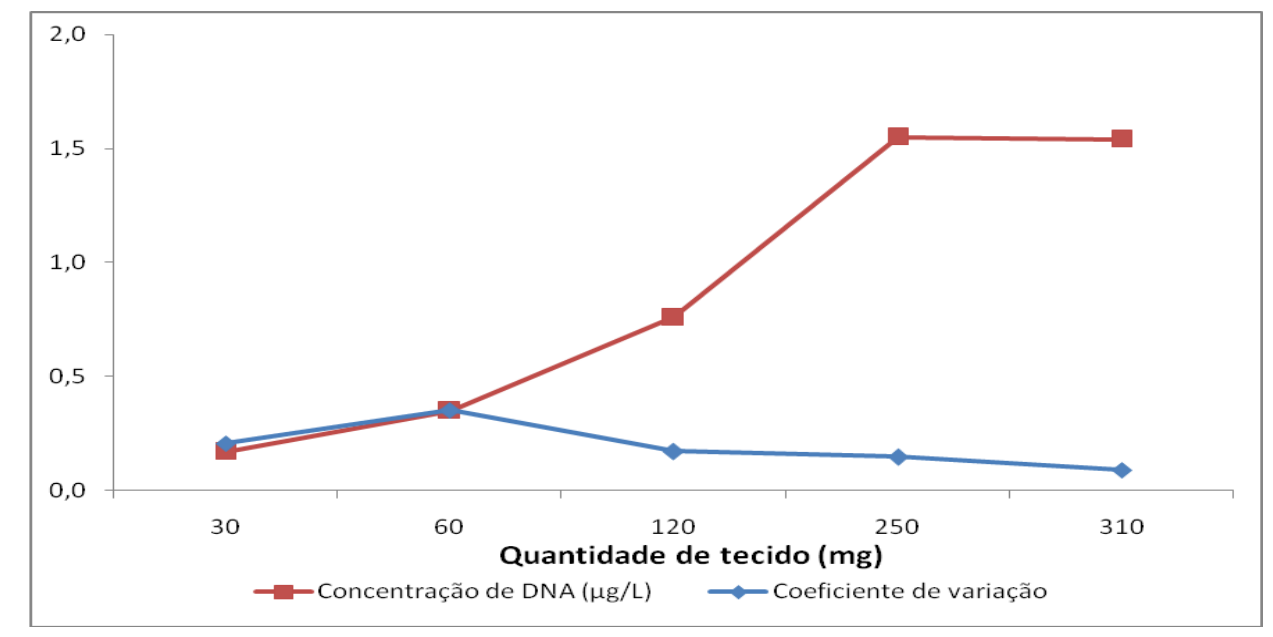

Fonte: os autores.

A partir dos resultados do tratamento $A$, a quantidade de $120 \mathrm{mg}$ de tecido bovino foi utilizada nas extrações de DNA por "CTAB" e "Salting out" na realização do tratamento $\mathrm{B}$.

Os dados obtidos na realização do tratamento B estão apresentados na Tabela 3. Pode-se observar que houve pouca variação entre as variáveis concentração de DNA e rendimento das amostras, sendo os maiores valores médios para o volume de $300 \mu \mathrm{L}$ de solução tampão de extração no protocolo "CTAB" e valores intermediários para este volume no protocolo "Salting out". O coeficiente de variação apresentou valor mais baixo e intermediário, respectivamente para o protocolo "CTAB" e "Salting out", para $300 \mu \mathrm{L}$ de tampão. E as médias do índice de pureza ficaram no intervalo de 1,4 a 2,0, indicando boa qualidade de todas as amostras.

Desta forma, o volume de $300 \mu \mathrm{L}$ de solução tampão de extração foi considerado o mais adequado para ser utilizado em ambos os protocolos, considerando-se também a questão do consumo desta solução por ser este o menor volume entre os testados. 
Análises de extrações de DNA: ponto de partida para aplicações biotecnológicas na área da biologia molecular

Tabela 3 - Média dos resultados obtidos (6 repetições) no tratamento B, nos dois protocolos.

\begin{tabular}{c|c|c|r|r|c}
\hline Protocolo & $\begin{array}{c}\text { Quantidade } \\
\text { tampão }(\boldsymbol{\mu L})\end{array}$ & $\begin{array}{c}\text { Concentração } \\
\text { DNA }(\boldsymbol{\mu g} / \boldsymbol{\mu L})\end{array}$ & $\begin{array}{c}\text { Rendimento } \\
(\boldsymbol{\mu g} / \mathbf{m g})\end{array}$ & Pureza & $\begin{array}{c}\text { Coeficiente } \\
\text { variação }(\%)\end{array}$ \\
\hline \multirow{3}{*}{ "CTAB" } & $\mathbf{3 0 0}$ & $\mathbf{1 , 0 6}$ & $\mathbf{0 , 8 8}$ & $\mathbf{1 , 7 6}$ & $\mathbf{6 , 6 8}$ \\
\cline { 2 - 6 } & 500 & 0,91 & 0,75 & 1,79 & 10,39 \\
\cline { 2 - 6 } & 700 & 0,92 & 0,77 & 1,51 & 12,30 \\
\hline \multirow{2}{*}{$\begin{array}{c}\text { "Salting } \\
\text { out" }\end{array}$} & $\mathbf{3 0 0}$ & $\mathbf{0 , 8 9}$ & $\mathbf{0 , 7 4}$ & $\mathbf{1 , 8 6}$ & $\mathbf{1 2 , 1 8}$ \\
\cline { 2 - 6 } & 500 & 0,95 & 0,76 & 1,79 & 11,00 \\
\hline
\end{tabular}

No tratamento $C$, a partir dos resultados dos tratamentos $A$ e $B$, utilizou-se $120 \mathrm{mg}$ de tecido animal e $300 \mu \mathrm{L}$ de solução tampão de extração. A avaliação dos resultados indicou que a padronização da quantidade de sobrenadante retirado na etapa de purificação do DNA (tratamento C) não diferiu muito do estabelecido nos protocolos (padrão), para as variáveis avaliadas (Tabela 4).

Tabela 4 - Média dos resultados obtidos (6 repetições) no tratamento C utilizando o os dois protocolos.

\begin{tabular}{c|c|c|c|c|c}
\hline Protocolo & Tratamento & $\begin{array}{c}\text { Concentração } \\
\text { DNA }(\boldsymbol{\mu g} / \boldsymbol{\mu L})\end{array}$ & $\begin{array}{c}\text { Rendimento } \\
(\boldsymbol{\mu g} / \mathbf{m g})\end{array}$ & Pureza & $\begin{array}{c}\text { Coeficiente } \\
\text { variação (\%) }\end{array}$ \\
\hline \multirow{2}{*}{ "CTAB" } & C & 0,75 & 0,61 & 2,00 & 21,90 \\
\cline { 2 - 6 } & Padrão & 0,88 & 0,72 & 1,77 & 20,39 \\
\hline \multirow{2}{*}{$\begin{array}{c}\text { "Salting } \\
\text { out" }\end{array}$} & C & 0,73 & 0,51 & 1,77 & 12,66 \\
\cline { 2 - 6 } & Padrão & 0,86 & 0,70 & 2,09 & 23,16 \\
\hline
\end{tabular}

Através deste projeto de pesquisa foi possível estabelecer algumas modificações nos dois protocolos de extração de DNA utilizados. Os valores de 120 mg de tecido (tratamento A) e $300 \mu \mathrm{L}$ de solução tampão de extração (tratamento B) foram adotados para a prática do laboratório, enquanto o volume de sobrenadante (fase aquosa com DNA) transferido durante a etapa de purificação (tratamento C) não foi alterado com relação ao recomendado nos protocolos iniciais. 
Análises de extrações de DNA: ponto de partida para aplicações biotecnológicas na área da biologia molecular

\section{Efeito da temperatura na conservação de DNA extraído de tecido animal}

O terceiro projeto visou avaliar a taxa de degradação de amostras de DNA extraídas de músculo bovino, submetidas a diferentes temperaturas de conservação. As amostras foram analisadas quanto a concentração e qualidade do DNA extraído.

A primeira etapa envolveu a comparação de extrações de DNA mantidas em baixas temperaturas com amostras à temperatura ambiente. Neste projeto amostras de $200 \mathrm{mg}$ de tecido muscular bovino foram submetidas a quatro tratamentos: temperatura ambiente, geladeira $\left(4^{\circ} \mathrm{C}\right)$, freezer $\left(-20^{\circ} \mathrm{C}\right)$ e ultrafreezer $\left(-80^{\circ} \mathrm{C}\right)$. O DNA foi extraído no primeiro dia e após 30, 60 e 90 dias, com seis repetições em cada, utilizando os protocolos "CTAB" e "Salting out".

$\mathrm{Na}$ análise dos resultados, foram observadas correlações negativas significativas $(p<0,05)$ entre a concentração do DNA e o tempo de conservação. Os valores para o protocolo "CTAB" foram: temperatura ambiente $(r=-0,685), 4^{\circ} \mathrm{C}(r=-$ $0,635),-20^{\circ} \mathrm{C}(r=-0,508)$ e $-80^{\circ} \mathrm{C}(r=-0,491)$. No protocolo "Salting out": temperatura ambiente $(r=-0,607), 4^{\circ} \mathrm{C}(r=-0,551),-20^{\circ} \mathrm{C}(r=-0,805)$ e $-80^{\circ} \mathrm{C}(r=-0,545)$.

Após 30 dias, a diminuição na concentração do DNA das amostras mantidas a temperatura ambiente foi de $86 \%$ no protocolo "CTAB" e $71 \%$ no protocolo "Salting out", a $4^{\circ} \mathrm{C}$ de $21 \%$ no "CTAB" e $15 \%$ no "Salting out", a $-20^{\circ} \mathrm{C}$ de $56 \%$ no "CTAB" e $58 \%$ no "Salting out" e a $-80^{\circ} \mathrm{C}$ de $50 \%$ no "CTAB" e $57 \%$ no "Salting out". Após 90 dias, a redução da concentração de DNA foi de 90\% no "CTAB" e 61\% no "Salting out", nas amostras à temperatura ambiente, enquanto que a $4^{\circ} \mathrm{C},-20^{\circ} \mathrm{C}$ e $-80^{\circ} \mathrm{C}$ a redução foi, respectivamente, de 71\%, 53\% e 44\% no "CTAB" e de $80 \%, 72 \%$ e $61 \%$ no "Salting out". As diferenças na concentração de DNA obtidas entre os 30 e 90 dias não foram significativas ( $p>0,05)$, provavelmente devido à alta variação nos resultados dentro dos tratamentos.

Os resultados demonstraram que a degradação do DNA pode ser reduzida através da utilização de baixas temperaturas, sendo a conservação das amostras a $80^{\circ} \mathrm{C}$ a que alcançou o melhor resultado. No maior período em conservação, 90 dias, a redução da concentração de DNA foi de 56\% em extrações realizadas com o uso do protocolo "CTAB" e 40\% como o uso do protocolo "Salting out". Com relação aos índices de pureza, o protocolo "CTAB" apresentou os maiores valores em comparação ao protocolo "Salting out", indicando a sua melhor adequação aos tratamentos avaliados. 
$\mathrm{Na}$ segunda etapa comparou-se a degradação de amostras mantidas sob refrigeração e em temperatura elevada. Amostras de $200 \mathrm{mg}$ de tecido muscular bovino foram submetidas a quatro tratamentos, temperatura ambiente, estufa $\left(45^{\circ} \mathrm{C}\right)$, geladeira $\left(4^{\circ} \mathrm{C}\right)$ e freezer $\left(-20^{\circ} \mathrm{C}\right)$. O DNA foi extraído no primeiro dia e após $7,14,21$ e 28 dias, com seis repetições cada, utilizando-se somente o protocolo "CTAB".

Os resultados desta etapa podem ser observados na Figura 3. Na análise dos dados obtidos, observou-se uma correlação negativa significativa $(p<0,05)$ entre o dia da extração e a concentração do DNA nas amostras a temperatura ambiente ( $r=$ $-0,734), 45^{\circ} \mathrm{C}(r=-0,728)$ e $-20^{\circ} \mathrm{C}(r=-0,49)$, enquanto que, para as amostras mantidas a $4^{\circ} \mathrm{C}$, a correlação não foi significativa $(r=-0,108)$. Avaliando as extrações realizadas aos 28 dias (maior tempo de conservação), a redução da concentração de DNA foi significativamente diferente entre os tratamentos $(H=13,42, p<0,05)$, alcançando $85 \%$ de degradação nas amostras a temperatura ambiente, $90 \%$ das amostras a $45^{\circ} \mathrm{C}, 26 \%$ a $4^{\circ} \mathrm{C}$ e $47 \%$ a $-20^{\circ} \mathrm{C}$.

Figura 3 - Variação na concentração de DNA extraído de amostras mantidas em diferentes temperaturas.

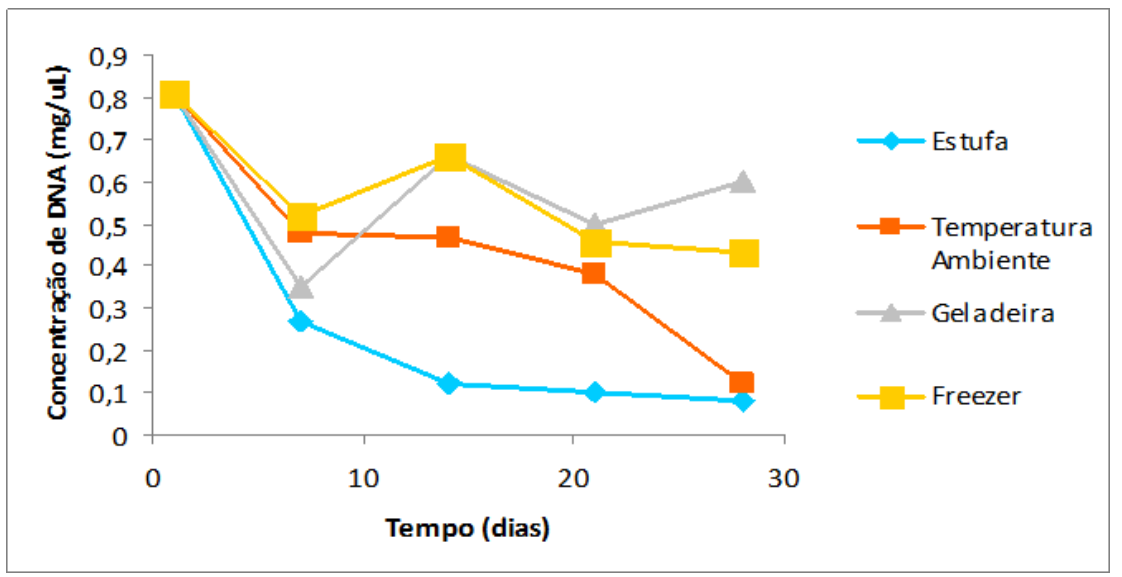

Os resultados demonstram que embora as baixas temperaturas tenham reduzido a degradação do DNA em relação às amostras mantidas na estufa e à temperatura ambiente, esta estratégia não foi totalmente eficaz para a conservação das amostras. 


\section{Efeito de diferentes conservantes na taxa de degradação do DNA extraído de tecido animal}

O objetivo do quarto projeto de pesquisa foi analisar o efeito, ao longo do tempo, de diferentes conservantes sobre a degradação do DNA extraído de amostras de tecido animal, utilizando o protocolo "CTAB".

Amostras de $200 \mathrm{mg}$ de tecido muscular bovino foram submetidas a quatro tratamentos de conservação: sem conservantes à temperatura ambiente $(A)$ e etanol $70 \%(B)$, etanol absoluto (C) e conservante RNAlatter (Ambion, D), mantidos em geladeira $\left(4^{\circ} \mathrm{C}\right)$. O DNA foi extraído no primeiro dia e após $7,14,21,28$ e 60 dias de conservação, com 6 repetições por dia para cada um dos 4 tratamentos.

Neste trabalho, observou-se redução da concentração de DNA ao longo do tempo nas amostras sem conservantes e mantidas à temperatura ambiente $(A)$, sendo que após 60 dias, maior tempo em conservação, a redução foi de $85 \%$ em relação à concentração de DNA inicial (Figura 4). Aos 60 dias, nos tratamentos com conservantes, a redução foi de $37 \%$ nas amostras conservadas em etanol absoluto, $65 \%$ nas amostras em etanol $70 \%$ e $83 \%$ nas amostras em "RNAlatter" (Figura 4 ).

Figura 4 - Concentração de DNA extraído de tecido bovino, no primeiro dia e após 7, 14, 21, 28 e 60 dias mantidos sem conservantes e em temperatura ambiente e em etanol absoluto, etanol $70 \%$ e "RNAlatter", a $4^{\circ} \mathrm{C}$.

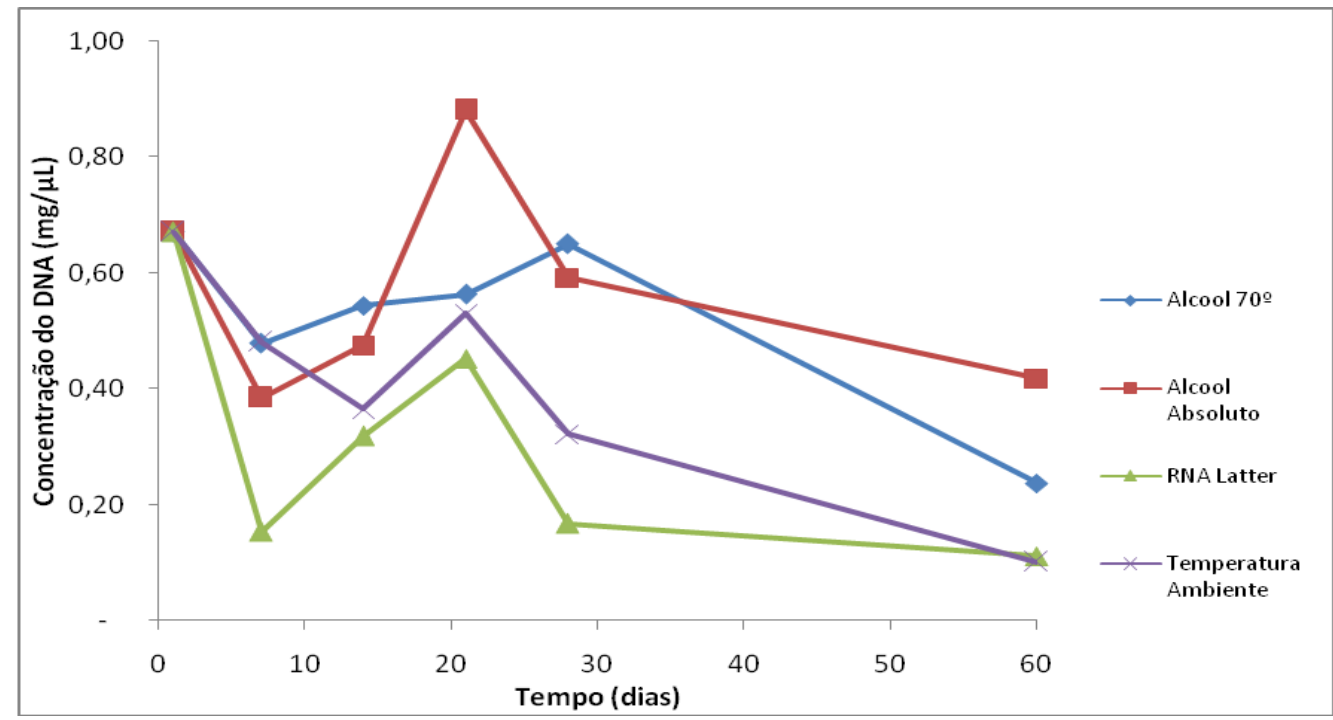

Comparando-se os valores médios de concentração de DNA nas extrações e o tempo de conservação, as amostras mantidas sem conservantes e a temperatura 
ambiente, apresentaram correlação negativa significativa ( $r$ : $-0,594, p<0,05)$. Igualmente, uma correlação negativa significativa $(p>0,05)$ foi observada nas amostras em etanol 70\% (r: -0,514) e em "RNAlatter" (r: -0,418). Entretanto, a correlação não foi significativa quando utilizado etanol absoluto ( $r:-0,162, p>0,05)$.

De um modo geral, os melhores resultados foram obtidos de extrações realizadas a partir de amostras mantidas em etanol absoluto, sendo esta considerada a melhor estratégia de preservação de tecido bovino por um maior tempo de conservação.

\section{CONCLUSÕES}

As diversas aplicações da Biotecnologia enfatizam a necessidade de se obter DNA, por protocolos de extração, em concentrações adequadas, íntegro e com bom índice de pureza. Entretanto, as extrações podem ser afetadas por diferentes fatores relativos a realização da técnica, tal como, o protocolo utilizado, o tipo e a quantidade de amostra inicial e mesmo a forma de conservação das amostras antes das extrações, incluindo a temperatura e conservantes em que as amostras biológicas são mantidas, caso necessário (SEUTIN et al. 1991; BAREA et al., 2004; SOLLÉRO et al. 2004; SIMONATO et al., 2007; ZIMMERMANN et al. 2008; SCORSATO e TELLES, 2011).

Os quatro projetos desenvolvidos pela linha de pesquisa, descritos neste artigo, alcançaram os objetivos propostos, de avaliar variáveis relevantes relativas à técnica de extração de DNA. Adicionalmente, propiciaram aprendizado ao grupo, especialmente contribuindo com a formação técnica dos envolvidos na sua realização.

No desenvolvimento do primeiro projeto de pesquisa, o uso do protocolo "CTAB" (modificado) resultou em extrações de DNA com maior concentração e qualidade. Este resultado é devido, especialmente, pelo fato deste protocolo ter sido desenvolvido (DOYLE e DOYLE, 1987) e ser utilizado principalmente para tecidos vegetais, tal como citado por Molinari e Crochemore (2001) e Santos e Araújo (2017). As extrações apresentaram menor degradação e oxidação de DNA, face a adição do reagente $\beta$-mercaptoetanol (anti-oxidante) na solução de lise no momento da extração, e menor contaminação por proteínas, devido ao uso de clorofórmio, um desnaturante proteico forte. O protocolo "Salting out", por sua vez, foi desenvolvido e 
é eficaz para fluidos, como sangue, mas não apresentou tão bons resultados para folhas. As extrações apresentaram rendimento intermediário e contaminação por proteínas em algumas amostras, sendo que neste protocolo a eliminação das proteínas se dá por alta concentração salina. Adicionalmente, as amostras de DNA exibiram um pouco de degradação, talvez pelo fato do reagente $\beta$-mercaptoetanol já estar na solução tampão de extração. O protocolo "Sílica" corresponde a um kit comercial desenvolvido por empresa gaúcha de análises em biologia molecular, especialmente para fluidos (plasma). Este kit não resultou em boas extrações de DNA a partir de folhas. A hipótese é que as moléculas de DNA não tenham sido liberadas totalmente das partículas de sílica devido a dificuldades físicas, como compostos de sustentação das plantas. A análise em espectrofotômetro indicou concentração muito pequena e com índice de pureza inadequado, em grande parte das amostras.

No projeto 2, a opção foi utilizar os protocolos "CTAB" e "Salting out" e avaliar a quantidade de tecido inicial, o volume da solução tampão de extração e o volume da fase aquosa com DNA (sobrenadante), recuperada durante a etapa de purificação, para extração de DNA a partir de tecido animal (músculo bovino). Ao analisar a quantidade de amostra inicial, observou-se que, apesar do aumento na concentração de DNA obtido, o excesso de tecido pode afetar o rendimento e aumentar a variação nos resultados. Desta forma, os melhores resultados foram para a quantidade inicial de $120 \mathrm{mg}$ de músculo bovino, em ambos protocolos, entretanto o intervalo entre 120 e $250 \mathrm{mg}$ pode ser utilizado com bons valores de extração. Na avaliação do volume da solução tampão de extração, o aumento desta em relação a quantidade de tecido inicial não resultou em melhores resultados nas amostras de DNA obtidas, sendo o menor volume, $300 \mu \mathrm{L}$, considerado o mais adequado para ser utilizado nos dois protocolos, levando-se também em conta a questão do consumo desta solução. Quanto a quantidade de sobrenadante recuperada na etapa de purificação do DNA indica-se o uso do volume padrão descrito nos dois protocolos, por não ter sido observado diferença considerável nos resultados.

Os projetos 3 e 4 envolveram a análise da conservação das amostras de tecido animal, músculo bovino, até o momento da extração. O projeto 3 avaliou temperaturas de conservação das amostras e o projeto 4, o uso de conservantes. Estes projetos basearam-se no fato de que diversos fatores resultam na degradação 
dos tecidos biológicos, seja pela demora entre a coleta e o processamento das amostras no laboratório ou também devido ao tempo transcorrido após a morte do indivíduo, no caso de análises forenses em cadáveres em avançada decomposição (SALEHI e NAJAFI, 2014). Desta forma, quanto maior o tempo transcorrido entre a obtenção das amostras de tecidos e o seu processamento, maior a possibilidade de que os ácidos nucléicos presentes nestes sejam degradados, resultando na impossibilidade da obtenção de DNA adequado para as análises moleculares (FORAN, 2006). Após a coleta, a degradação das amostras ao longo do tempo resulta em perdas no rendimento e na pureza do DNA, constituindo um fator limitante para a o sucesso das análises (ITANI et al., 2011; MICHAUD e FORAN, 2011; KARNI et al. 2013).

Assim, a conservação das amostras biológicas é, portanto, um fator essencial para a realização das análises moleculares de maneira eficiente, existindo diferentes processos empregados para este fim, incluindo além da redução da temperatura das amostras, o emprego de fixadores e de conservantes que impedem a degradação específica dos ácidos nucléicos (SCORSATO e TELLES, 2011). Destaca-se ainda que, embora o DNA seja uma molécula reconhecida como estável (KARNI et al. 2013), sendo possível sua detecção em amostras arqueológicas de elevada idade (HAGELBERG et al. 2015), Foran (2006) já havia observado a elevada degradação do DNA em tecidos animais mantidos sob alta temperatura por uma semana, indicando o congelamento como controle. Naia (2014), ao analisar a concentração do DNA em amostras de tecidos humanos, concluiu que existe uma relação entre o intervalo post mortem, com aumento da degradação com o passar do tempo, mas com influência de fatores como temperatura, umidade a tamanho da amostra.

A redução da temperatura é uma estratégia muito utilizada para a diminuição da degradação de materiais biológicos, sendo recomendada para a manutenção de amostras biológicas entre a coleta e a análise (MELO et al. 2010). Os dados obtidos no projeto 4 demonstraram que, embora uma redução na taxa de conservação de músculo bovino tenha sido obtida para temperaturas de $4^{\circ} \mathrm{C}$ (geladeira), a eficácia da redução da temperatura na conservação das dos tecidos animais não é total. Após 30 dias, observou-se perda de até 57\% de DNA, em amostras mantidas a $80^{\circ} \mathrm{C}$ (ultrafrezer). O mesmo foi relatado por ALMEIDA et al. (2009), que verificaram a ocorrência de degradação do DNA em amostras mantidas a baixas temperaturas, tendo sido indicada a possibilidade da quebra do DNA mantido em freezer, o que 
está de acordo com as recomendações de manuais de conservação de amostras (CLINICAL AND LABORATORY STANDARDS INSTITUTE, 2005).

Quanto ao uso de conservantes, salienta-se que é preciso verificar a aplicabilidade destes em diferentes amostras e avaliar a sua vantagem técnica e financeira sobre os demais procedimentos (MUTTER et al., 2004; GELBART et al., 2012). Os resultados do projeto 4 indicaram considerável redução na taxa de degradação de DNA nas amostras mantidas em álcool etílico 70\% e absoluto, com melhores resultados para o último. Os resultados observados com o uso do conservante "RNAlatter" não foram melhores dos obtidos de amostras a temperatura ambiente e sem uso de conservantes.

Em resumo, os projetos sobre extração de DNA desenvolvidos pelo grupo de pesquisa do NIEB do IFRS-POA indicaram que: entre os protocolos comparados para extração o mais adequado foi o "CTAB" (DOYLE e DOYLE, 1987), especialmente para vegetais; as quantidades de $120 \mathrm{mg}$ de tecido e $300 \mu \mathrm{L}$ de solução tampão de extração são bons valores para serem utilizados nos protocolos "CTAB" e "salting out" para extração de DNA de músculo bovino; as baixas temperaturas $\left(4^{\circ} \mathrm{C}\right)$ ou etanol absoluto são as melhores estratégias, entre as testadas, para a conservação de amostras de músculo bovino até o momento da extração.

\section{REFERÊNCIAS}

ALMEIDA, G.C.; MONTAGNER, F.; ENDO, M.S.; GOMES, B.P.F.A. Detecção da degradação do DNA genômico extraído através da espectofotometria e da reação de PCR. $11^{\circ}$ Seminário de Extensão UNIMEP, Piracicaba. 2009.

BAREA, J.A.; PARDINI, M.I.M.C.; GUSHIKEN, T. Extração de DNA de materiais de arquivo e fontes escassas para utilização em reação de polimerização em cadeia (PCR). Revista Brasileira de Hematologia e Hemoterapia 26 (4): 274-281. 2004.

BOOM, R.; SOL, C.J.A.; SALIMANS, M.M.M.; JANSEN, C.L.; WERTHEIM-VAN DILLEN, P.M.E.; VAN DER NOORDAA, J. Rapid and simple method for purification of nucleic acids. Journal Clinical Microbiology, 28: 495-503. 1990.

CLINICAL AND LABORATORY STANDARDS INSTITUTE. MM13-A-Collection, Transport, Preparation, and Storage of Specimens for Molecular Methods; Approved Guideline. CLSI document MM13-A. 2005. 
DOYLE, J.J.; DOYLE, J.L. A rapid DNA isolation procedure for small quantities of fresh leaf tissue. Phytochemical Bulletin, 9 (1): 11 - 15. 1987.

FORAN, D.R. (2006) Relative Degradation of Nuclear and Mitochondrial DNA: An Experimental Approach. Journal of Forensic Science 51 (4): 766-770.

GELBART, T.; GAO, N.; MONDALA, T.S.; KURIAN, S.M.; OLTHOFF, K.M.; ABECASSIS, M.; SALOMON, D.R. Comparison of RNA, DNA, small RNA (including miRNA) and protein yields from liver biopsy samples using two commercially available tissue preservation reagents: RNALater and AlIProtect. 2012. http://transplantgenomics.genetics.ucla.edu/files/RNALatervsAIIProtectComparison.pdf.

HAGELBERG, E.; HOFREITER, M.; KEYSER, C. Ancient DNA: the first three decades. Philosophical Transactions of the Royal Society B., 370: 20130371. 2013.

ITANI, M.; YAMAMOTO, Y.; DOI, Y.; MIYAISHI, S. Quantitative Analysis of DNA Degradation in the Dead Body. Acta Medica Okayama, 65 (5): 299-306. 2011.

KARNI, M.; ZIDON, D.; POLAK, P.; ZALEVSKY, Z.; SHEFI, O. Thermal Degradation of DNA. DNA and Cell Biology, 32 (6): 298-301. 2013.

MELO, M.R.; MARTINS, A.R.; BARBOSA, I.V.; ROMANO, P.; SHCOLNIK, W. Coleta, transporte e armazenamento de amostras para diagnóstico molecular. Jornal Brasileiro de Patologia e Medicina Laboratorial 46 (5): 375-381. 2010

MICHAUD, C.L.; FORAN, D.R. Simplified Field Preservation of Tissues for Subsequent DNA Analyses. Journal of Forensic Science, 56 (4): 846-852. 2011.

MILLER, S.A.; DYKES, D.D.; POLESKY, H.F. A simple salting out procedure for extracting DNA from human nucleated cells. Nucleic Acid Research. 16: 1215. 1988.

MOLINARI, H.B.; CROCHEMORE, M.L. Extração de DNA genômico de Passiflora spp. para análises PCR-RAPD. Revista Brasileira Fruticultura, 23, n.2, 447-450. 2001.

MUTTER, G.L.; ZAHRIEH, D.; LIU, C.; NEUBERG, D.; FINKELSTEIN, D.; et al. Comparison of frozen and RNALater solid tissue storage methods for use in RNA expression microarrays. BMC Genomics 5: 88. 2004.

NAIA, M.J.T. Determinação do Intervalo Postmortem através do decréscimo de citrato e DNA em ossos: Influência das condições tropicais. Dissertação de mestrado em medicina legal. Universidade Católica de Petrópolis. 2014.

SALEHI, Z.; NAJAFI, M. RNA Preservation and Stabilization. Biochemistry and Physiology 3: 126. 2014. 
SAMBROOK, J.; RUSSELL, D.W. Molecular cloning. A laboratory manual. Cold Spring Harbor Press, New York. 2001.

SANTOS, E.M.; ARAUJO, R.R. Testes de comparação de protocolos de extração de DNA e de maceração de tecido de Platonia insignis Mart. (Clusiaceae).

Revista Brasileira Biociências, Porto Alegre, v. 15, n.4, p. 199-202, out./dez. 2017.

SCORSATO, A.P.; TELLES, J.E.Q. Fatores que interferem na qualidade do DNA extraído de amostras biológicas armazenadas em blocos de parafina. Jornal Brasileiro de Patologia e Medicina Laboratorial., 47 (5): 541-548. 2011.

SEUTIN, G.; WHITE, B.N.; BOAG, P.T. Preservation of avian blood and tissue samples for DNA analyses. Canadian Journal of Zoology, 69 (1): 82-90. 1991.

SIMONATO, L.E.; GARCIA, J.F.; NUNES C.M.; MIYAHARA, G.I. Avaliação de dois métodos de extração de DNA de material parafinado para amplificação em PCR. Jornal Brasileiro de Patologia e Medicina Laboratorial, 43 (2): 121-127. 2007.

SOLLÉRO, B.P.; DE FARIA, D.A.; PAIVA, S.R.; GUIMARÃES, S.E.F.; LOPES, P.S.; PAIXÃO, D.M. Método Rápido de Extração de DNA Utilizando CTAB em tecidos musculares de Suínos. ZOOTEC2004, Brasília, DF. 2004.

ZIMMERMANN, J.; HAJIBABAEI, M.; BLACKBURN, D.C.; HANKEN, J.; CANTIN, E.; POSFAI, J.; EVANS JR, T.C. DNA damage in preserved specimens and tissue samples: a molecular assessment. Frontiers in Zoology, 5: 18. 2008. 